https://doi.org/10.18485/iipe_postkovid.2021.ch16

\title{
PRISTUPANJE EVROPSKOJ UNIJI U VREME KRIZE - ZAPADNI BALKAN I NEUSPELA REFORMA POLITIKE PROŠIRENJA
}

\begin{abstract}
Andrijana LAZAREVIĆ ${ }^{1}$
Nemanja PURIĆ2

Apstrakt: Najvažnija dimenzija politike proširenja Evropske unije jeste njen evolutivni karakter, a Unija je upravo početkom devedesetih godina 20. veka, kao odgovor na zahtev izmenjenih političkih okolnosti u Centralnoj i Istočnoj Evropi, kreirala politiku proširenja čije su institucionalne osobenosti uslovljene prethodnim talasima proširenja. Dodatno, svaka naredna reforma predstavljala je reakciju na slabosti koje su se pokazale tokom i nakon pristupanja država u prethodnom talasu proširenja. Međutim, reforma nakon pristupanja Bugarske, Rumunije i Hrvatske nije dala odgovarajuće rezultate. Ovaj razlog, ali i niz institucionalnih slabosti i političkih prilika u državama Zapadnog Balkana, kao i u samoj Uniji, rezultirali su zahtevom za promenom metodologije pristupanja. Nova metodologija, iako promovisana sa ambicijom da obezbedi brži, kredibilniji i transparentniji proces pristupanja država Zapadnog Balkana, ni dve godine kasnije nije dala odgovarajuće rezultate. Politika proširenja, determinisana unutrašnjim izazovima u funkcionisanju Unije, kao i zastojem reformi u državama u procesu pristupanja, sada se nalazi u (trajnom) zamoru. Rad analizira evolutivnu prirodu politike proširenja, potencijal nove metodologije da odgovori na problem trajnog zamora kao i status Republike Srbije i njen kapacitet da na datom nivou pregovora primeni novu metodologiju u
\end{abstract}

\footnotetext{
${ }^{1}$ Istraživač pripravnik, Institut za političke studije, Beograd. E-mail: andrijana.lazarevic@ ips. ac.rs.

Rad je nastao u okviru naučno-istraživačke delatnosti Instituta za političke studije, koju finansira Ministarstvo prosvete, nauke i tehnološkog razvoja Republike Srbije.

${ }^{2}$ Istraživač pripravnik, Fakultet političkih nauka, Univerzitet u Beogradu. E-mail: nemanja.puric@fpn.bg.ac.rs.

Rad je nastao u okviru projekta „Politički identitet Srbije u regionalnom i globalnom kontekstu" koji se sprovodi na Fakultetu političkih nauka, Univerziteta u Beogradu.
} 
cilju ostvarenja brže dinamike pregovora. U pokušaju da odgovore na prethodno kandidovana pitanja, autori polaze od osnovne hipoteze da je neuspeh reforme politike proširenja determinisan multidimenzionalnom krizom Unije, kao i međuvladinim pristupom u reformi institucionalnog dizajna same politike.

Ključne reči: politika proširenja, Zapadni Balkan, vladavina prava, nova metodologija, Republika Srbija

\section{Evolucija politike proširenja}

Koncept pristupanja novih članica integralni je deo života svake međunarodne organizacije, bez obzira na koji način se odvija. To važi i za Evropsku uniju odnosno Evropsku zajednicu kao entitet sa nadnacionalnim obeležjima. lako je do Velikog proširenja 2004. godine pristupilo ukupno devet država, ${ }^{3}$ o pregovorima možemo govoriti više kao diplomatskim, a manje kao strukturiranim. Međutim, pad Berlinskog zida, stvaranje Evropske unije i ambicija velikog broja država Centralne i Istočne Evrope ka pristupanju, uticale su na Uniju da krene u pravcu institucionalizacije pridruživanja (sa perspektivom članstva), a zatim i pristupanja. Zahtev velikog broja država sa sličnim političkim i ekonomskim problemima motivisali su Uniju da stvori novu politiku čije institucionalne osobenosti procesa pristupanja daleko prevazilaze zahteve tipičnih međunarodnih organizacija. Nakon unutrašne reforme i usvajanja ugovora iz Mastrihta, na samitu u Kopenhagenu 1993. godine prvi put su precizno definisani uslovi koje svaka država u procesu pristupanja mora da ispuni. Kriterijume iz Kopenhagena možemo podeliti na politički, ekonomski i pravni, uz dodatni uslov koji nazivamo apsorpcioni kapacitet Evropske unije, odnosno „sposobnost Unije da odgovori na izazove uvećanja članstva“.4

To znači da država u procesu pristupanja mora da bude tržišna ekonomija sa dovoljno razvijenim političkim sistemom koji će podržati demokratske vrednosti koje Unija i njene države članice promovišu, ali i sa kapacitetom da apsorbuje njene pravne tekovine (acquis). Tome treba dodati i administrativni

\footnotetext{
${ }^{3}$ Ujedinjeno Kraljevstvo Velike Britanije i Severne Irske, Irska i Danska u pristupile 1973. godine, Grčka 1981. godine, Španija i Portugalija 1986. godine, a Austrija, Švedska i Finska 1995. godine. lako je politika proširenja nastala pre 1995. godine, ona se nije odnosila na ove tri države.

${ }^{4}$ Tanja Miščević, Pridruživanje Evropskoj uniji, Beograd, Službeni glasnik, 2009, str. 147.
} 
kriterijum iz Madrida, promovisan 1995. godine, koji naglašava nužnost stvaranja administrativnih kapaciteta države koja pristupa, a koji će biti u mogućnosti da podrže sam proces pristupanja, ali i buduće članstvo u Uniji. ${ }^{5}$

Dakle, u pitanju je pristup koji nije orijentisan samo na proces pristupanja u institucionalnom smislu, već daje mogućnost Uniji da u datom regionu deluje transformativno, što se i pokazalo na primeru država centralne $i$ istočne Evrope. ${ }^{6}$ On predstavlja izuzetan institucionalni napredak u odnosu na prethodne talase proširenja. Pre Kriterijuma iz Kopenhagena jedini (institucionalni) uslovi mogli su se naći u osnivačkim ugovorima i naglašavali su da država koja ima perspektivu članstva u Zajednici, odnosno Uniji, mora biti evropska država, koja poštuje evropske vrednosti. ${ }^{7}$ Evropske vrednosti nikada nisu precizno definisane, uprkos činjenici da termin u literaturi predstavlja dati okvir, a sam zahtev možemo okarakterisati kao minimalan i sveden na deklarativnu promociju demokratije i ljudskih prava u ustavima država koje pregovaraju o članstvu. ${ }^{8}$ Ipak, Kriterijumi iz Kopenhagena ceo proces pristupanja država centralne i istočne Evrope institucionaliziju, pružajući im okvir koji za razliku od prethodnih talasa proširenja umanjuje diplomatsku dimenziju pregovora, prednost dajući tehničkim aspektima uz poseban naglasak na politički i ekonomski kriterijum. ${ }^{9}$

Dakle, ovi koraci značili su stvaranje jedne od najmlađih i najuspešnijih politika Unije, koja je stvorila u datom trenutku uspešan okvir za pristupanje deset država centralne, istočne i južne Evrope. ${ }^{10}$ Institucionalnu potporu činili

\footnotetext{
${ }^{5}$ Madrid European Council, Presidency Conclusions, 15 and 16 December 1995, Internet: https://www.europarl.europa.eu/summits/mad1_en.htm\#toc, 03/06/2021.

${ }^{6}$ Maja Kovačević, „,Kriza u Evropskoj uniji i politika proširenja“ u: Slobodan Samardžić i Ivana Radić Milosavljević (urs), Evropska unija: Nove i stare dimenzije krize, Fakultet političkih nauka Univerziteta u Beogradu, 2016, str. 83-91.

${ }^{7}$ Videti: Art. 49, Art. 2, Consolidated version of the Treaty on European Union, OJC 202/43, Internet: https://eur-lex.europa.eu/legal-content/EN/TXT/?uri=LEGISSUM\%3Al14536

${ }^{8}$ Dimitry Kochenov, "Behind the Copenhagen façade, The meaning and structure of the Copenhagen political criterion of democracy and the rule of law", European Integration online Papers (EloP), 10:8, 2004, p. 2.

${ }^{9}$ George Vassiliou, The Accession Story: The EU from Fifteen to Twenty-Five Countries, Oxford University Press, UK, 2007, p. 27.

${ }^{10}$ Veliko proširenje podrazumeva pristupanje Češke, Slovačke, Poljske, Mađarske, Slovenije, Estonije, Letonije, Litvanije, Kipra i Malte 2004. godine.
} 
su i Agenda proširenja, Pretpristupna strategija i Pristupno partnerstvo. ${ }^{11}$ Prilikom pristupanja ovih država sam proces percipiran je kao trijumf, a region Centralne i Istočne Evrope kao trajno transformisan u demokratski i stabilan. Značajno proširena Evropska unija postala je čuvar evropskih vrednosti u državama koje su se vratile u Evropu.

lako su na početku bile deo istog talasa proširenja, Bugarskoj i Rumuniji nije omogućeno da pristupe 2004. godine. To predstavlja značajan trenutak, a možemo i reći jednu od prekretnica u razvoju politike proširenja Evropske unije. Prvo, ocenjujući da su Rumunija i Bugarska nespremne da pristupe sa ostalim državama, neposredno pre sastanka Evropskog saveta Kopenhagenu 2002. godine doneta je Mapa puta za ove dve države. ${ }^{12}$ Drugo, u samom dokumentu je naglašeno da države nisu spremne da pristupe 2004. godine, ali im je u isto vreme pružena jasna perspektiva članstva 2007. godine. lako je jasno da je uspeh proširenja na Istočnu i Centralnu Evropu u tom trenutku bio veliki, ispostaviće se da je Unija postupila previše entuzijastično, dajući još nespremnim državama izvestan datum. Posledično, iako je nemogućnost obe države da ispune kriterijume u oblasti vladavine prava glavni razlog odlaganja datuma pristupanja, sada, sa jasnom perspektivom (gotovo garancijom) članstva, Rumunija i Bugarska su u periodu do pristupanja bile izložene striktnijem uslovljavanju nego druge zemlje CIE, između ostalog i zbog nižih startnih demokratskih performansi. Stoga, ove dve države se nalaze pod Verifikacionim mehanizmom prema kojem Evropska komisija redovno izveštava o napretku reformi u oblasti vladavine prava u obe države. ${ }^{13}$ Ovaj instrument se 13 godina od trenutka pristupanja i dalje primenjuje. U kontekstu ovog rada, to znači da države koje ne mogu da ispune kriterijume za pristupanje, sada kao članice imaju priliku da ocenjuju napredak u vladavini prava u državama koje su trenutno u procesu pristupanja. To naravno

\footnotetext{
${ }^{11}$ Andrea Matijević, „Stavovi država članica o proširenju Evropske unije i nova metodologija politike proširenja", Politička revija, Institut za političke studije, 64:2, 2019, str. 155.

${ }^{12}$ Communication from the Commission to the Council and the European Parliament Roadmaps for Bulgaria and Romania, 13 November 2002, Internet: https://www.cvce. eu/en/obj/commission_communication_roadmaps_for_bulgaria_and_romania_13_nove mber_2002-en-8b3baa32-a4ed-4fb8-ac61-46fafd698170.html, 03/06/2021.

${ }^{13}$ Cooperation and Verification Mechanism for Bulgaria and Romania, Internet: https://ec. europa.eu/info/policies/justice-and-fundamental-rights/upholding-rule-law/rule-law/ assistance-bulgaria-and-romania-under-cvm/cooperation-and-verification-mechanismbulgaria-and-romania_en, 03/06/2021.
} 
stvara odnos asimetrije, a dodatno i potkopava kredibilnost procesa koji Unija dugo i uz veliki napor kreira na način da pruža sigurnost i jednake uslove za države u procesu pregovora. Ipak, pojedinačni uticaj država članica na proces pristupanja analiziraćemo u delu koji se odnosi na novu metodologiju.

Kao što smo na samom početku naglasili, evolutivna priroda jeste najvažnija dimenzija politike proširenja. S obzirom na to da Unija stalno uči na svojim iskustvima, slučaj Bugarske i Rumunije imao je institucionalne posledice po politiku proširenja prema Zapadnom Balkanu. Politika proširenja počinje ubrzano da se kreće u pravcu, možemo slobodno reći, i hiperinstitucionalizacije (poredeći sa konceptom pristupanja u tipičnim međunarodnim organizacijama). Prvi korak čini promovisanje novog pristupa u pregovorima o članstvu (New Approach to the EU Negotiations) koji je podrazumevao uvođenje merila (benchmarks) za otvaranje i zatvaranje poglavlja, prvo za Hrvatsku, a zatim i za Crnu Goru i Srbiju, za koje merila postaju obavezna. To znači da država koja pregovara članstvo mora ispuniti date kriterijume za samo otvaranje poglavlja, kao i za njegovo privremeno zatvaranje. ${ }^{14}$ Dodatno, za poglavlja 23 (Reforma pravosuđa, borba protiv korupcije i ljudska i manjinska prava) i 24 (Pravda, sloboda i bezbednost) predviđaju se i prelazna merila (interim benchmarks) koja za cilj imaju praćenje napretka u ova dva poglavlja. ${ }^{15}$ Sada se ova dva poglavlja otvaraju prva, a zatvaraju poslednja (fundamentals first), dok klauzula o balansu (imbalance clause) omogućava zaustavljanje pregovora o pristupanju u slučaju neispunjavanja obaveza iz poglavlja 23 i $24 .{ }^{16}$

Ova reforma ima za cilj da predupredi „nove slučajeve Bugarske i Rumunije“ te da svim stranama pruži sigurniji, precizniji i kredibilniji pregovarački proces. ${ }^{17}$ To je naročito slučaj sa agendom, na kojoj se sada na vrhu nalaze najteža pitanja, pre svega vladavina prava, reforma javne uprave, ali i bilateralni problemi sa

\footnotetext{
${ }^{14}$ Enlargement Strategy and Main Challenges 2012-2013, Communication from the Commission to the European Parliament and the Council, dostupno na: https://ec. europa.eu/neighbourhood-enlargement/sites/near/files/pdf/key_documents/2012/ package/strategy_paper_2012_en.pdf (Pristupljeno 3.6.2021)

15 Ibid.

${ }^{16}$ Andrea Matijević, „Stavovi država članica o proširenju Evropske unije i nova metodologija politike proširenja", op. cit., str. 156.

${ }^{17}$ Tanja Miščević, Mojmir Mrak, "The EU Accession Process: Western Balkans vs EU-10", Croatian Political Science Review, Vol. 54, No. 4, 2017, pp. 185-204, p. 192.
} 
državama članicama. Najveći dobitnici reforme su zapravo države članice koje sada uz mogućnost ocenjivanja merila imaju veću kontrolu nad pregovaračkim procesom. Broj merila konstantno raste, a Srbija i Crna Gora imaju dva puta više merila od Hrvatske. ${ }^{18}$ lako se takav institucionalni razvoj na prvi pogled čini adekvatnim, on ipak otvara niz izazova o kojima ćemo rapravljati u nastavku.

\section{Nova metodologija - stari problemi}

U ovom trenutku, devet odnosno sedam godina od odluke o otvaranju pregovora sa Crnom Gorom i Srbijom, ali i (suštinskim) problemima oko početka pregovora sa Albanijom i Severnom Makedonijom, sasvim je jasno da reforma politike proširenja nije dala rezultate. Nekoliko je važnih faktora koji su uticali na slabe performanse ove institucije. Prvo, iako se često navodi kao jedini razlog, što je jednostran i samo delimično tačan zaključak, nazadovanje u pogledu vladavine prava u državama Zapadnog Balkana blokira proces pristupanja. Zabrinjavajuće autoritarne tendencije i ne samo stagnacija već i nazadovanje na polju vladavine prava imale su svoj odjek u izveštajima o napretku, ali i u stručnoj literaturi u kojoj se sve više govori o pojmu stabilokratije, odnosno stanju u kojoj se u državama Zapadnog Balkana, ali iz perpektive Evropske unije više vrednuje politička stabilnost po cenu nazadovanja demokratskih procesa, što naravno ima svoju cenu u pogledu brzine pristupanja Uniji. ${ }^{19}$

Drugo, postavlja se pitanje adekvatnosti metodologije, ali i zahteva koji se u njoj nalaze. Fundamentalni značaj koji se daje vladavini prava u pretpristupnom procesu čini se upitan na dva nivoa. „Sam termin je bezobalan i neprecizan i da se, što je još važnije, ne podudara sa pojmovima ljudska prava, demokratija, sloboda itd. kako se često pogrešno posmatra. Ti pojmovi jesu deo koncepta vladavine prava, ali se nikako ne mogu izjednačiti. Pojam vladavine prava se u osnivačkim ugovorima Unije pominje kao jedna od temeljnih vrednosti, ali se pri tome ne definiše tačno značenje. Čak ni u članu 7 Ugovora koji govori o posledicama u slučaju povrede člana 2 od strane države članice nemamo

${ }^{18}$ Tanja Miščević, „Savremeni izazovi politike proširenja Evropske unije na Zapadni Balkan“, Politička misao, br. 2, 2016, str. 139.

${ }^{19}$ Videti više u: Maja Kovačević, „Evropska unija i Zapadni Balkan: kako raskinuti 'prećutni pakt stabilokratije'?", Zbornik radova sa međunarodne naučne konferencije Sukobi. Stabilnost. Demokratija?, Fakultet političkih nauka, Beograd, 2019, str. 9-23. 
dodatno pojašnjenje. ${ }^{20} \mathrm{~S}$ druge strane, zabrinjavajuće tendencije u Mađarskoj i Poljskoj, državama koje su članice Unije već 16 godina, zapravo ukazuju na sumnju da je prvobitno dizajnirana politika proširenja Unije prema državama centralne i istočne Evrope uspela da trajno transformiše te regione. Na politiku proširenja to, kao što smo videli, jeste imalo snažan uticaj, ali se postavlja pitanje kredibileta Unije u svojoj politici uslovljavanja. To nas dovodi do problema koji autori nazivaju dilema i dvostruka dilema vladavine prava. ${ }^{21}$ Ukoliko države članice nemaju konsenzus oko toga šta zapravo znači vladavina prava (dilema), postavlja se pitanje kapaciteta država Zapadnog Balkana za razumevanje samog termina, ali i njegove primene u praksi (dvostruka dilema). Smatramo da je u kontekstu metodologije proširenja kocept moguće produbiti i nadograditi uvođenjem trostruke dileme vladavine prava, koja pored prethodno navedenih problema postavlja pitanje sposobnosti Unije da formira adekvatan sistem ocenjivanja napretka u polju vladavine prava.

Treće, kao što smo prethodno naglasili, dalja institucionalizacija i uvođenje merila omogućili su državama članicama veću ulogu u procesu pristupanja. Kao nenameravana posledica institucionalizacije javila se tendencija država članica da blokirajući proces pristupanja rešavaju bilateralne probleme sa državama članicama. Svesne svog ucenjivačkog potencijala, države članice (u najvećem broju slučaja države susedi) blokiraju otvaranje poglavlja, daju negativnu ocenu za merila ili, što je najradikalnije, blokiraju početak pregovora o pristupanju. Naravno, najpoznatiji primer jeste problem Grčke i Severne Makedonije oko imena ove bivše jugoslovenske republike. lako je rešavanje ovog dugogodišnjeg problema Prespanskim sporazumom dovelo Severnu Makedoniju na korak do početka pregovora, konstatni zahtevi Bugarske za rešavanje identitetskih pitanja dodatno komplikuju situaciju. ${ }^{22}$ Slični problemi prate prvo i proces pridruživanja, a zatim i pristupanja Republike Srbije. Uslovljavanje rešavanja problema oko privatizacije Beogradske industrije piva (BIP) ratifikacijom Sporazuma o

\footnotetext{
${ }^{20}$ Ivan Milovanović i Nemanja Purić, „Politika proširenja Evropske unije i fundamentalni značaj vladavine prava", u: Boban Stojanović, Miljana Pejić, Nikola Jović (urs), Zbornik radova, Krovna organizacija mladih Srbije - KOMS, Beograd, 2019.

${ }^{21}$ Tanja Miščević, "Legislative obligations of Serbia in the accession process to the European Union - The case of fundamental rights", in: Zoran Pavlović (ed.), Yearbook Human Rights Protection "From Unlawfulness to Legality", 2018:1, pp. 333-349.

22 Prespanski sporazum, dostupno na: Internet: https://vlada.mk/sites/default/files/dokumenti /spogodba-en.pdf, 03/06/2021.
} 
stabilizaciji i pridruživanju, nesuglasice sa Rumunijom i Bugraskom oko pitanja nacionalnih manjina, ali i problem granice na Dunavu, kao i pitanje migrantske krize sa Hrvatskom usporili su i dodatno politizovali procese pridruživanja i pristupanja Srbije. Setimo se, za svaku reformu politike proširenja Unija kao jedan od najvažnijih ciljeva kandiduje upravo veću kredibilnost procesa.

Četvrto, negativno iskustvo sa novim državama članicama kao i multidimenzionalna kriza unutar Unije izazvana ekonomskim činiocima, dubokim podelama po pitanju budućnosti evropske integracije, problemom vladavine prava, istupanjem Ujedinjenog Kraljevstva Velike Britanije i Severne Irske, kao i najnovijom krizom izazvanom pandemijom Kovid 19 virusom, ne samo da su usporile proces pristupanja već su ozbiljno dovele u pitanje budućnost politike proširenja. Holandija je jedan od najboljih primera države članice koja je duboko protiv skorog pristupanja bilo koje države Zapadnog Balkana. Stalno naglašavajući važnost balansirane politike proširenja i suštinske transformacije država, ${ }^{23}$ Holandija je nekoliko puta odložila početak pregovora sa Albanijom i Severnom Makedonijom, što ponovo naglašava problem preteranog uticaja država članica na sam proces pristupanja. Istina, potrebno je istaći da je i na samom početku institucionalizacije politike proširenja uticaj država članica na Veliko proširenje bio veliki. ${ }^{24}$ Naravno, u tom trenutku je vladao optimizan po pitanju novih članica Unije, ali je sasvim jasno da je uticaj država članica po pitanju proširenja jedna od glavnih konstanti celog procesa.

Svi ovi faktori doveli su politiku proširenja u stanje zamora (enlargement fatigue), odnosno nemogućnosti Unije da na adekvatan način podrži dinamičan proces pristupanja država Zapadnog Balkana. lako sam pojam nije nov, o njemu se aktivno govori još od pristupanja Hrvatske 2013. godine, a zatim i izjave tadašnjeg predsednika Komisije, Žan Klod Junkera, da za vremene mandata Komisije u periodu 2014-2020. neće biti proširenja. ${ }^{25}$ Usled veoma slabe dinamike u prethodnom periodu, ali i velikog razočaranja Severne Makedonije i Albanije po pitanju stavova država članica, pre svega Holandije i Francuske, čuli

${ }^{23}$ The Role of the Netherlands in EU Enlargement Processes: A Potential Staller to the EU's External Stability, Hague Centre for Strategic Studies.

${ }^{24}$ Helen Wallace, William Wallace, Mark A. Pollack, Policy-Making in the European Union, Oxford University Press, 2005, p. 409.

${ }^{25}$ The Juncker Commission: A strong and experienced team standing for change, Internet: https://ec.europa.eu/commission/presscorner/detail/en/IP_14_984, 03/06/2021. 
su se sve glasniji zahtevi za promenom metodologije pristupanja. Francuska je u novembru 2019. godine učinila prvi korak u tom pravcu i uputila non-paper (non pejper) sa smernicama za izmenjenu metodologiju pristupnih pregovora. Glavna novina predstavljena u ovom dokumentu jeste promena značaja pojedinačnih pregovaračkih poglavlja koji su do sada pojedinačno otvarana. Francuska ideja jeste kreiranje sedam nivoa ili tačnije klastera u kojima će se nalaziti tematski srodna poglavlja. Otvaranjem poglavlja iz svakog nivoa država kandidat bi trebalo, barem teroijski, da bude fokusirana na srodna poglavlja, a samim tim i efikasnija u reformama. ${ }^{26} \mathrm{Na}$ kraju je predstavljeno šest klastera, ali je ideja ostala ista. ${ }^{27}$ Novi princip klastera prate i četiri nova principa proširenja: 1. postepena integracija; 2 . precizni uslovi; 3 . opipljiva korist; 4. reverzibilnosti. ${ }^{28}$

Međutim, iako se čine kao novi, principi su zapravo samo unapređeni. Prvo, na samom početku ideje o novoj metodologiji, postepena integracija promovisana je kao najambiciozniji i najinovativniji princip. lako se to nije eksplicitno naglašavalo, o postepenoj integraciji se razmišljalo kao o diferenciranoj integraciji, što se ispostavilo kao protivno osnivačkim ugovorima. Naime, nije moguće u potpunosti biti deo neke od politika Unije ukoliko nemate mogućnost glasanja u procesu donošenja odluka, a to pravo uživaju samo države članice. Na kraju, princip je promovisan kao ideja veće koristi iz različitih fondova Unije pre samog pristupanja. Drugo, precizni uslovi, a naročito u oblasti vladavine prava, čiji je značaj ponovo naglašen, nisu novi, već samo modifikovana merila koja smo pominjali u kontekstu prethodne reforme politike proširenja. Treće, proces reverzibilnosti, ponovo stavljen u kontekst vladavine prava, novi je naziv za klauzulu o balansu.

Stoga, nova metodologija, osim forme klastera koji imaju svoje prednosti i koji sasvim sigurno treba da donesu novu dinamiku u proces pristupanja, $u$ suštinskom smislu ne nudi nove principe. Ona naravno predstavlja novu fazu u istoriji politike proširenja, međutim njen potencijal da unese obećanu dinamiku

\footnotetext{
${ }^{26}$ Non-Paper Reforming the European Union accession process, November 2019.

27 "Communication from the Commission to the European Parliament, the Council, the European Economic and Social Committee and the Committee of the Regions Enhancing the accession process - A credible EU perspective for the Western Balkans", European Commission, Brussels, 5.2.2020 COM(2020) 57 final, Internet: https://ec.europa.eu/ neighbourhood-enlargement/sites/near/files/enlargement-methodology_en.pdf, 03/06/2021.

28 Ibid.
} 
predvidljivost i kredibilnost u poređenju sa prethodnim stanjem ostaje vrlo upitna. lako je metodologija zvanično predstavljena u februaru 2020. godine, do decembra nije učinjen vidljiv napredak u državama Zapadnog Balkana. Crna Gora jeste otvorila poslednje poglavlje, ali Albanija i Severna Makedonija, prema kojima je nova metodologija na prvom mestu i usmerena, još uvek nisu počele svoje pregovore. S druge strane, slučaj Srbije je svakako najkompleksniji, pre svega jer se 18 otvorenih poglavlja nalazi u svim klasterima, pa je dalja dinamika otvaranja klastera dugo vremena bila nejasna.

Imajući u vidu da se Zapadni Balkan suočava sa nizom problema ekonomske prirode, ali i zabrinjavajućim tendencijama kada su u pitanju demokratski kapaciteti država, a da se usled niza kriza koje su se desile u prethodnih deset godina politika proširenja našla nisko na agendi Unije, kao i da nova metodologija nije dala odgovarajuće početne rezultate, $u$ ovom trenutku možemo izneti ocenu o trajnom zamoru proširenja. Postavlja se pitanje uzroka takvog stanja. Da li je u pitanju samo multidimenzionalna kriza sa kojom se suočava Unija ili je u pitanju dvostrani odnos uslovljen i slabim rezultatima u reformama u državama kandidatima, a pre svega u oblasti vladavine prava? Kao i pitanje, sam odgovor nije jednodimenzionalan, pa ćemo u nastavku analizirati situaciju tokom kovid krize, kao i trenutno stanje politike proširenja.

\section{Multidimenzionalna kriza Evropske unije - pandemija Kovid 19, politički izazovi i politika proširenja}

Sam početak 2020. izgledao je kao obećavajući sa aspekta politike proširenja. Predstavljena je nova metodologija koja je obećavala veću dinamiku pregovora, Ujedinjeno Kraljevstvo je istupilo iz Evropske unije, a Savetom Evropske unije su u narednih godinu dana trebale da predsedavaju Hrvatska i Nemačka. U pitanju su dve države koje su, svaka sa svoje pozicije, veoma zainteresovane za politiku proširenja. Hrvatska, kao nekada deo Zapadnog Balkana, sada je veoma zainterovana da zadrži uticaj u regionu, a Nemačka kao veliki pokrovitelj politike proširenja, ali i regionalnih inicijativa na Zapadnom Balkanu sada je želela da pruži dalji podsticaj proširenju.

Međutim, kriza izazvana pandemijom virusa Kovid 19 na samom početku negativno je uticala na percepciju Evropske unije kao aktera u državama Zapadnog Balkana. Na početku krize vest da je Unija 15. marta 2020. godine 
zabranila izvoz medicinske opreme, ${ }^{29}$ što uključuje i države Zapadnog Balkana izazvala je veliko razočaranje. U naslovu vesti koju su preneli mediji navedena je reč „zabranila“, a kasnije su neki mediji promenli reč u naslovu u „ograničila“. U stvarnosti se radi o implementirajućem aktu Komisije koja obavezuje izvoznike da traže dozvolu od nadležnih vlasti države članice u kojoj imaju sedište..$^{30}$ lako je vest ispravljena, $u$ javnosti je veoma negativno percepirana, pre svega jer je predstavljena u svetlu krize proširenja nedostatka solidarnosti i negativne percepcije od strane država članica.

S druge strane, kada je u pitanju samo proširenje, Hrvatska je kao jedan od glavnih zadataka svog predsedavanja predstavila održavanje samita o Zapadnom Balkanu, prvog posle Sofije 2018. godine. Možemo primetiti da su za 20 godina održana samo četiri samita posvećena Zapadnom Balkanu, a da su dva održana u poslednje dve godine. U oba slučaja Savetom Evropske unije predsedavale su države bliske regionu Zapadnog Balkana koje su kroz svoju agendu predsedavanja želele sebe da promovišu kao aktera u regionu. Za razliku od Samita u Solunu 2003. godine, kada je potvrđena evropska perspektiva Zapadnog Balkana, što je na tadašnjem stepenu integracija imalo snažan odjek, samiti u Zagrebu i Sofiji imali su skromnije domete. lako se od samita u Sofiji, prvog posle 15 godina očekivalo mnogo, u samoj deklaraciji se ne pominje reč proširenje. ${ }^{31}$ Potvrđena je evropska perspektiva iz Soluna, ali nije dat dovoljno jak podstrek za dalje proširenje. Isto važi i za Zagrebačku deklaraciju, koja ponovo ne pominje reč proširenje. ${ }^{32}$

Ipak, imajući u vidu da se hrvatsko debitantsko predsedavanje Unijom desilo u veoma lošem političkom trenutku, kao i da je uz sve napore Samit ipak održan, za države Zapadnog Balkana je u ovom trenutku trajnog zamora politike proširenja veoma važno da se još uvek nalaze na agendi Unije. To može dati

29 „EK ograničava izvoz medicinske opreme van EU“, Radio Slobodna Evropa, 15. mart/ožujak, 2020, Internet: https://www.slobodnaevropa.org/a/30489356.html , 03/06/2021.

30 "COMMISSION IMPLEMENTING REGULATION (EU) 2020/402 of 14 March 2020 making the exportation of certain products subject to the production of an export authorization", Official Journal of the European Union, L 77 I.

${ }^{31}$ Sofijska deklaracija, 17. maj 2018. godine, Internet: https://www.consilium.europa.eu/ media/34806/sofia-declaration_me.pdf, 03/06/2021.

32 Zagrebačka deklaracija, 6. maj 2020. godine, Internet: https://www.consilium.europa.eu/ media/43789/zagreb-declaration-bs-06052020.pdf, 03/06/2021. 
podsticaj da se i dalje radi na reformama, kao i da proces evropskih integracija i dalje bude unutrašnja politička tema.

Nemačko predsedavanje nije donelo novine. Na samoj agendi predsedavanja politika proširenja ostaje veoma nisko, i što je zabrinjavajuće, u delu koji postavlja prioritete sa trećim državama i međunarodnim organizacijama, Rusijom, Centralnom Azijom i ASEAN-om. ${ }^{33}$ Takav tretman je dosta zabrinjavajući, ali nemački zvaničnici ostaju pri stavu da Nemačka ostaje posvećena regionu Zapadnog Balkana i izdradnji snažne regionalne saradnje. S druge strane, imajući u vidu da je najveći izazov predsedavanja balansiran i pre svega za sve strane prihvatljiv budžet Unije, jasno je da politika proširenja u ovom trenutku ne može biti prioritet.

Veliki problem kredibiliteta politike proširenja u ovom trenutku predstavlja i prethodno pomenuti slučaj Severne Makedonije. Nakon Prespanskog sporazuma sa Grčkom, bugarski zahtevi oko identitetskih pitanja i blokada početka pregovora još jednom su pokazali slabosti politike proširenja. Setimo se prethodno iznetih zapažanja o novoj metodologiji. Snažnija politička dimenzija u praksi znači snažniji podsticaj upotrebe veta od strane država koja pokušavaju da reše svoje bilateralne probleme. Slabost je u institucionalnom smislu i očekivana jer svaka reforma politike proširenja zapravo zadržava međuvladin pristup. Države i dalje ostaju jedini gospodari horizontalne integracije, a bilateralni problemi dominantan faktor. Primena pravila u praksi nam pokazuje da je najveća slabost politike zapravo jednoglasno odlučivanje. Ideja većinskog glasanja nije nova, ali slično kao i u tipičnim međunarodnim organizacijama, ali i drugim politikama Unije, sasvim je jasno da se države članice veoma teško odriču jednoglasnosti (posledično prava veta) kao instrumenta uticaja na treće države.

Stoga, imajući u vidu tu činjenicu, ali i stalnu potrebu za većom dinamikom, kao jedno od mogućih rešenja nameće se ideja podele na važne i ostale odluke u procesu pristupanja o kojima bi se glasalo većinski i jednoglasno. Važne odluke bi bile status kandidata, početak pregovora o članstvu i sporazum o pristupanju, a ostale odluke, o kojima bi se odlučivalo većinski, bile bi odluke o otvaranju klastera kao i privremenom zatvaranju klastera. Na taj način, početak tehničkih reformi ne bi zavisio od političke dimenzije pregovora, a države koje imaju

\footnotetext{
33 Programme for Germany's Presidency of the Council of the European Union, Internet: https://www.eu2020.de/blob/2360248/e0312c50f910931819ab67f630d15b2f/06-30pdf-programm-en-data.pdf, 03/06/2021.
} 
nameru da rešavaju svoje bilateralne probleme ne bi bile u mogućnosti da blokiraju ceo proces.

Svi ovi faktori doprinose stanju koje nazivamo trajni zamor politike proširenja. Posmatrajući pristupanje 13 država, od kojih neke kao što smo rekli i u ovom trenutku nisu u mogućnosti da ispune sve kriterijume koji su se od njih očekivali u trenutku pristupanja, ostaje veoma važno pitanje imperativa današnje politike proširenja da nije moguće rešavati pitanja i izazove kroz članstvo, već isključivo pre članstava. Hiperinstitucionalizacija i pravo veta konstantno usporavaju proces, podižući lestvicu očekivanja čak i za ostvaranje poglavlja, a sada klastera. Države članice sada, za razliku od prethodnih pristupanja nemaju potrebu da čekaju odgovarajući trenutak za rešavanje bilateralnih problema (što je u najvećem broju prethodnih slučajeva bila kulminacija pregovora pred potpisavanje sporazuma o pristupanju), već sada u potpunosti blokiraju i sam početak pregovora. Poredeći sa čuvenom mataforom štapa i šargarepe, možemo reći da nagrada, odnosno motivacija za države kandidate za dalje reforme sada postaje neprivlačna, a predstavljanje reformi kao političkog rezultata donosioca odluka bez težine. Sve to su nenameravane posledice institucionalnog dizajna koji nameće novu potrebu za novom reformom, pre nego što je stara i počela sa implementacijom.

\section{Umesto zaključka: Republika Srbija i perspektiva pristupanja}

Imajući u vidu prethodno navedeno, možemo reći da je dinamika i perspektiva Srbije u procesu pristupanja u potpunosti u skladu sa stanjem trajnog zamora celokupne politike proširenja. Institucionalno posmatrano, dinamika otvaranja pregovaračkih poglavlja veoma je slaba, sa svega 18 otvorenih poglavlja. Ono što još više zabrinjava jeste činjenica da Srbija u 2020. godini nije otvorila nijedno novo pregovaračko poglavlje, uz izjave komesara Varheljija da postoje izgledi da do kraja godine otvori jedno poglavlje (poglavlje 8: Politika konkurencije). ${ }^{34}$ To se nije desilo, ali je pre samog pitanja otvaranja poglavlja u fokusu analize zbunjujuća situacija primene nove metodologije.

\footnotetext{
34 Izjava Komesara za susedstvo i proširenje Olivera Varheljija, 07.10.20, Briefing, Internet: https://betabriefing.com/news/politics/12391-varhelyi-serbia-can-open-one-chapter-thisyear-on-competition-policy, 03/06/2021.
} 
Prethodno pitanje koje se nametalo jeste sam pristanak i promovisanje nove metodologije kao validne za Republiku Srbiju. Predsednik Republike Srbije Aleksandar Vučić, u julu 2020. godine, prilikom zvanične posete predsedniku Francuske, Emanuelu Makronu, izjavio je da Srbija prihvata novu metodologiju. ${ }^{35}$

Prvo važno pitanje koje se nameće jeste da li izjava predsednika obavezuje. Prema normama međunarodnog javnog prava sasvim je jasno da izjave šefa države, šefa vlade i ministra spoljnih poslova obavezuju državu. Međutim, treba imati u vidu da je u pitanju bilateralna poseta jednog šefa države drugom šefu države, kao i da šef države nema ulogu tokom pregovora o pristupanju. Francuska kao država članica ima svoju ulogu u politici proširenja, ali pitanje primene nove metodlogije jeste pitanje za institucije Unije. Stoga, obaveznost date izjave, prvo u pogledu šefa države kao zainteresovanog lica, ali i u pogledu adresata tema je koja je otvorena za diskusiju sa međunarodno-pravne tačke gledišta.

Pitanje je više teorijske prirode jer je Evropska unija, odnosno Savet, dao zajedničku izjavu kojom potvrđuje da će se nova metodologija primenjivati na Crnu Goru i Srbiju. ${ }^{36}$ Izjava je data 11. maja 2021. godine, odnosno gotovo dve godine od prvih najava o izmeni metodologije pristupanja. U samom dokumentu ponovo je naglašena evropska perpektiva kao ključa transformacije celog regiona kao i osnovni principi nove metodologije. ${ }^{37}$ Međutim, u dokumentu nije naglašena potreba za institucionalnim prilagođavanjem metodologije slučajevima dve države i njihovim dosadašnjim rezultatima u procesu pristupanja. Stoga, postavlja se pitanje razloga zakasnelog odgovora Unije na samozadati cilj veće dinamike pregovora.

Drugi važan trenutak jeste negativan izveštaj o napretku. lako su ekonomske reforme pohvaljene, u oblasti vladavine prava, oblasti od koje kao što smo rekli zavisi zaustavljanje celokupnog procesa pristupanja, učinjen je veoma ograničen

35 „Vučić: Obavestio sam Makrona da Srbija prihvata novu metodologiju proširenja EU“, 10. 07.2020, European Western Balkans, Internet: https://europeanwesternbalkans.rs/vucicobavestio-sam-makrona-da-srbija-prihvata-novu-metodologiju-prosirenja-eu/, 03/06/2021.

${ }^{36}$ Council of the EU, Enlargement: new enlargement methodology will be applied to Montenegro and Serbia, Press release, 11 May 2021, Internet: https://www.consilium. europa.eu/en/press/press-releases/2021/05/11/enlargement-new-enlargementmethodology-will-be-applied-to-montenegro-and-serbia/, 03/06/2021.

37 Ibid. 
napredak dok je u oblasti reforme pravosuđa napredak u potpunosti izostao. ${ }^{38}$ Sam izveštaj, poredeći ga sa prethodnim ima oštriji ton, što govori u prilog očiglednoj stagnaciji reformi u cilju pristupanja Uniji. Naravno, raniji cilj pristupanja 2025. godine u skladu sa navedenim eksternim i internim izazovima u potpunosti je izostavljen.

Ova situacija nas vraća na pitanje motivacije za daljim reformama, odnosno pitanjem - šta je uzrok a šta posledica? Da li je motivacija u državama Zapadnog Balkana izostala zbog trajno stopiranog pitanja proširenja uzrokovanog multidimenzionalnom krizom u Uniji, ali i državama članicama, ili je proces stopiran zbog nedostatka temeljnih reformi u državama kandidatima? Slučajevi Severne Makedonije i Srbije nam sugerišu da je problem dvostran, ali i da ga treba tražiti pojedinačno, od slučaja do slučaja.

Sasvim je sigurno da veliku prepreku adekvatnoj institucionalnoj transformaciji u pogledu načina glasanja predstavlja međuvladin pristup donošenju odluka, ali i da slabe institucionalne reforme, pre svega u pogledu vladavine prava, usporavaju transformaciju u miran razvojni region. Međutim, moć politike proširenja u pogledu transformativne moći leži u potencijalnoj nagradi za reforme. Sve dok nagrada nije kredibilna i izvesna, i dok su odnosi zasnovani na sistemu bilateralnih problema sa državama članicama, politika proširenja ostaje u trajnom zamoru.

\section{Literatura}

Consolidated version of the Treaty on European Union, OJC 202/43.

Kochenov, Dimitry, "Behind the Copenhagen façade, The meaning and structure of the Copenhagen political criterion of democracy and the rule of law", European Integration online Papers (EloP), 10:8, 2004.

Kovačević, Maja, „Kriza u Evropskoj uniji i politika proširenja“ u: Slobodan Samardžić i Ivana Radić Milosavljević (urs), Evropska unija: Nove i stare dimenzije krize, Fakultet političkih nauka Univerziteta u Beogradu, 2016.

\footnotetext{
38 "Serbia 2020 Report", Commission Staff Working Document, Internet: https://ec.europa.
} eu/neighbourhood-enlargement/sites/near/files/serbia_report_2020.pdf, 03/06/2021. 
Kovačević, Maja, „Evropska unija i Zapadni Balkan: kako raskinuti 'prećutni pakt stabilokratije'?", Zbornik radova sa međunarodne naučne konferencije Sukobi. Stabilnost. Demokratija?, Fakultet političkih nauka, Beograd, 2019.

Kovačević, Maja, „Politika proširenja Evropske unije u potrazi za reformom“, Politička revija, Institut za političke studije, 64:2, 2019.

Matijević, Andrea, „Stavovi država članica o proširenju Evropske unije i nova metodologija politike proširenja", Politička revija, Institut za političke studije, 64:2, 2019.

Milovanović, Ivan i Purić, Nemanja, „Politika proširenja Evropske unije i fundamentalni značaj vladavine prava", u: Boban Stojanović, Miljana Pejić, Nikola Jović (urs), Zbornik radova, Krovna organizacija mladih Srbije - KOMS, Beograd, 2019.

Miščević, Tanja, "Legislative obligations of Serbia in the accession process to the European Union - The case of fundamental rights", in: Zoran Pavlović (ed.), Yearbook Human Rights Protection "From Unlawfulness to Legality", 2018:1.

Miščević, Tanja, Mrak, Mojmir, 2017. "The EU Accession Process: Western Balkans vs EU-10/", Croatian Political Science Review, Vol. 54, No. 4, pp. 185204.

Miščević, Tanja, Pridruživanje Evropskoj uniji, Beograd, Službeni glasnik, 2009.

Miščević, Tanja, „Savremeni izazovi politike proširenja Evropske unije na Zapadni Balkan", Politička misao, br. 2, 2016.

Vassiliou, George, The Accession Story: The EU from Fifteen to Twenty-Five Countries, Oxford University Press, UK, 2007.

Ugovor o Evropskoj uniji, OJC 202/43.

Wallace, Helen, William, Wallace, Mark, A. Pollack, Policy-Making in the European Union, Oxford University Press, 2005. 


\title{
ACCESSION TO THE EUROPEAN UNION IN TIMES OF CRISIS - THE WESTERN BALKANS AND THE FAILURE OF THE ENLARGEMENT POLICY REFORM
}

\begin{abstract}
The most important dimension of the European Union's enlargement policy is its evolutionary character. In the early 1990s, the Union, while responding to the changing political circumstances in Central and Eastern Europe, created an enlargement policy whose institutional features were conditioned by previous waves of enlargement. In addition, each subsequent reform was a response to the weaknesses that emerged during and after the accession of states in the previous wave of enlargement. However, the reform following the accession of Bulgaria, Romania and Croatia did not yield adequate results. For this reason, but also because of the institutional weaknesses and political circumstances in the countries of the Western Balkans, as well as in the Union itself, there was a request to change the accession methodology. The new methodology, although promoted with the ambition to provide a faster, more credible and transparent accession process for the Western Balkan countries, did not yield adequate results even two years later. Enlargement policy, determined by the internal challenges in the functioning of the Union as well as the stagnation of reforms in the countries in the accession process, is now (permanently) fatigue. The paper analyzes the evolutionary nature of enlargement policy, the potential of the new methodology to respond to the problem of permanent fatigue as well as the status of the Republic of Serbia and its capacity to apply the new methodology at a given level of negotiations in order to achieve faster negotiation dynamics. In an attempt to answer previously nominated questions, the authors start from the basic hypothesis that the failure of enlargement policy reform is determined by the multidimensional crisis of the Union as well as the intergovernmental approach to reforming the institutional design of the policy itself.
\end{abstract}

Keywords: enlargement policy, Western Balkans, rule of law, new methodology, Republic of Serbia. 